sparingly of his time and talents to all those endeavours to which he set his hand. His name was never associated with an organization which did not receive benefit from his aggressive interest and mature judgment. It was characteristic of him that despite the warnings of his physician and the urgings of his associates to lessen his activities, he carried through his visit to England in November 1947 because of his conviction that the matter of business which prompted the visit was of national importance to Canada. While he set a high standard of effort for himself, he was always most considerate and solicitous of the welfare of his associates.

He will be greatly missed by a host of friends in Canada, the United States and the British Isles.

J. G. B.

\title{
ERNEST FRANK SPURGEON
}

THE passing, on 20 August 1948, of Ernest Frank Spurgeon, at the age of 67 , deprived the Institute of one who had rendered long and devoted service to his profession and to his Company, the Prudential. He entered the service of that company as a junior clerk at Head Office on leaving school, and rose to the position of a Director which he held at the time of his death.

Spurgeon became a Fellow in 1906 . He served on the Council $1923^{-26}$ and ro28-34. He was Honorary Secretary 1929-31, and Vice-President 1931-33. He served as a tutor $1911_{-15}$ and $1919-20$, and he was an examiner 1920-27. His outstanding service to the profession was the revision of King's Text-book, the Institute of Actuaries' Text-book, Part II, a task entrusted to him by the Council and one which he completed in I922. King's Text-book had been in use for over thirty-five years, and is still remembered by the survivors of an older generation with gratitude and, indeed, with some affection for its remarkable lucidity. The devclopments which had taken place in actuarial science during that long period were such that more than a mere revision was necessary. In his review of Spurgeon's Text-bonk ( F.I.A. Vol. Liv, p. 104), Levine pays a tribute to Spurgeon for the 'very great success' with which he surmounted the difficulties of the task he undertook, adding that 'both he and the Institute are to be warmly congratulated on the result of his work'.

Spurgeon had been a tutor for some years, and in the rewriting of the textbook he had ever in his mind the needs of the student. As Levine said, 'his book is obviously the work of a very able and successful tutor'. Sir Alfred Watson, in the introduction to the new book, said that Spurgeon 'brought to his task the indispensable qualifications of long experience as a tutor and a conspicuous gift of exposition'.

Spurgeon's career with the Prudential was a varied one. On the introduction of National Health Insurance in 1912 he was transferred to that side of his Company's activities. He became 'Treasurer of the Prudential Approved Societies in $19 I_{4}$, and threw himself with zeal into that new field of activity where he did so much good work. He served on the Consultative Council of the Ministry of Health $1923^{-29}$. In 1925 , he returned to the life assurance side of the business and became Deputy General Manager under Sir Joseph Burn. He did not, however, forsake the field of National Health Insurance, for he simultaneously became a member of the Committee of Management of the Prudential Approved Societies, subsequently becoming Chairman. That position he held 
up to 5 July 1948, when the Approved Society system terminated. He served for a number of years on the Executive of the National Conference of Industrial Assurance Approved Societies, and became a Vice-President in I94I.

Spurgeon retired on reaching pension age in $194 \mathrm{I}$, and was thereupon appointed a Director, in which position his wide and varied experience still remained at the disposal of the Company he had served so long.

Spurgeon had for many years been a member of the Actuaries' Club. His interests included a love of sport. In his early days he played a good game of tennis, and he never lost his keen enthusiasm for cricket--even when in later life he took up golf in a quiet way. He was a man of kindly disposition, and had a host of friends who will ever cherish the happiest of memories of a loyal colleague and a staunch friend.

J. M. L. 